DOI

\title{
ПЕРСПЕКТИВИ ВПРОВАДЖЕННЯ СУЧАСНИХ ІННОВАЦИЙ В ОСВІТНЮ ДІЯЛЬНІСТЬ УНІВЕРСИТЕТУ
}

\author{
В. М. Запорожан, В. Й. Кресюн, О. П. Рогачевський, О. В. Чернецька \\ Одеський національний медичний університет
}

\section{PERSPECTIVES OF INTRODUCTION OF MODERN INNOVATION INTO EDUCATIONAL ACTIVITY OF THE UNIVERSITY}

\author{
V. M. Zaporozhan, V. Y. Kresyun, O. P. Rohachevskyi, O. V. Chernetska \\ Odessa National Medical University
}

\begin{abstract}
У статті розглянуто питання якості освітньої діяльності, засоби ії удосконалення шляхом використання сучасних інноваційних технологій.

The paper covers the issue of quality of the educational activity, ways of its improvement by using modern innovation technologies.
\end{abstract}

Вступ. Покращення підготовки лікарів відповідно до вимог сучасного ринку праці, конкурентоспроможних в Україні та на міжнародному рівні потребує модернізації навчально-виховного процесу, спрямування його на створення оптимальних умов для професійного становлення майбутніх фахівців.

В сьогоденні якість вищої освіти слід забезпечувати на трьох рівнях: європейському, національному та на рівні університету. В освітніх системах країн Європи головним є планування отриманих результатів навчального процесу - знань, компетенцій та навичок.

Основна частина. Інформатизація освіти, розвиток сучасного навчального процесу на підставі впровадження інформаційних технологій, методів інтерактивного навчання і нових напрямів самостійної роботи студентів, впровадження компетентнісного підходу спрямовані на вирішення завдань щодо підготовки спеціалістів відповідно до вимог освітніх стандартів нового покоління.

Ураховуючи глобалізацію знань, швидкі темпи накопичення та поширення інформації, що спостерігаються останні десятиліття 3 розвитком комп’ютерних технологій, стає надзвичайно актуальним пошук нових форм підготовки та подання інформації. У зв’язку із зазначеним зростає значимість підготовки та впровадження у навчальний процес електронних видань.
Одеський національний медичний університет $є$ одним із лідерів у запровадженні і використанні електронних видань (матеріали Всеукраїнської навчально-наукової конференції “Реалізація Закону України “Про вищу освіту” у вищій медичній та фармацевтичній освіті України”, Тернопіль, 2015 р.). Крім наукової бібліотеки, для співробітників університету вже 8 років в ОНМедУ функціонує електронна студентська бібліотека, в якій створено 61 електронну кафедральну навчально-методичну базу, є понад 4 тисячі електронних підручників та посібників, існують 5 читальних залів на 300 місць, які мають доступ до Wi-fi, на сайті університету розташовано блок бібліотеки, де $є$ on-line доступ до електронного каталогу бібліотеки та методичних матеріалів кафедр. Кількість звернень до Webсервера бібліотеки як співробітників, так і студентів неухильно зростає. Особливу увагу викликає віртуальний бібліотекар та електронна доставка документів. Однією з важливих форм бібліотеки з інформаційного забезпечення науково-дослідницької і лікувальної діяльності співробітників університету є доступ до міжнародних інформаційних баз даних. Починаючи з 2015 р., у нашому університеті відкрито BOO3 - ресурс HINARI. Розпочато роботу щодо створення на базі електронної бібліотеки Інституціонального репозитарію. Оновлено сайти кафедр, на яких розміщені комплекси навчально-

( ) В. М. Запорожан, В. Й. Кресюн, О. П. Рогачевський, О. В. Чернецька 
методичного забезпечення з дисциплін навчального плану мовами викладання (українська, російська, англійська). На клінічних кафедрах створено класи практичної підготовки студентів і інтернів, які обладнані комп’ютерами, фантомами тощо.

Традиційна система навчання основана на отриманні знань, тоді як оцінка спеціаліста ведеться за критеріями вмінь та навичок. Однією з нагальних проблем $є$ теоретична підготовка в поєднанні 3 низьким рівнем володіння практичними навичками. Сьогодні основна увага в медичній освіті приділяється якісним показникам. Першочерговим досягненням цієї мети є впровадження програм, методологія яких навчає не просто знань, а знань та вмінь. Головну увагу треба приділяти методам активного навчання як найбільш дійовим та результативним. Тому у світлі актуальних проблем сучасної охорони здоров'я необхідно активно шукати нові шляхи щодо підвищення якості освіти, більш широко впроваджувати перспективні новітні технології в структуру навчально-методичного процесу.

Для покращення якості навчального процесу в університеті:

- використовується фрагментарно дистанційна форма навчання та створюється методична база для її впровадження, особливо на кафедрах післядипломної освіти, а також кафедрах, що навчають студентів за спеціальністю “Фармація” із заочною формою навчання;

- здійснюється постійний системний внутрішній моніторинг якості освітньої діяльності;

- застосовується система управління вебресурсами навчальної програми зі спеціальностей та дисциплін на основі платформи Moodle (www. moodle.org), розповсюджується з відкритим кодом, яка має відомі переваги;

- активізовано проведення практики на більш якісному рівні з розширенням баз практики в установах соціальної служби (інтернати, геронтологічні центри, будинки для людей похилого віку тощо);

- впроваджено електронний журнал на 1-3 курcax;

- впроваджено нову методику рейтингування науково-педагогічного складу університету;

- модернізовано у листопаді 2015 р. проведення ректорського контролю за новою комп’ютерною програмою. Для контролю використовуються тестові завдання зразка “Крок” з усіх дисциплін навчального плану. Опитування студентів автоматизоване та проводиться дистанційне в два етапи у визначений термін, а результат якості відповіді отримує викладач у режимі on-line.

Навчання майбутніх лікарів починається з тренажерів, муляжів, імітаційних ігор за участю добровольців, але більш перспективними є методики, коли в ролі пацієнтів виступають професійні актори. Цінність методики “Стандартизований пацієнт” у тому, що студент може відпрацювати практичні навички на реальному пацієнті, у випадку помилок має змогу їх виправити, працює самостійно в умовах обмеженого часу. Така методика дозволяє не тільки навчати студента, але й контролювати отримані ним знання та вміння. ОНМедУ був партнером у виконанні проекту “Східноєвропейська мережа передового досвіду в галузі досліджень і розробок при хронічних захворюваннях CHRONEX-RD (MIS-ETC код 1840) в рамках спільної операційної програми “Румунія - Україна - Республіка Молдова”. Разом було проведено 23 тренінги, пройшло тренінги 355 учасників. У рамках гранту під час виконання програми було створено онлайн-платформу для дистанційного навчання, два кабінети для реалізації програми “Стандартизований пацієнт”.

На базі ОНМедУ активно працює Навчальноінноваційний центр практичної підготовки лікарів та студентів, оснащений обладнанням з першого до сьомого рівня реальності. Це обладнання дозволяє навчати студентів, інтернів, лікарів практично в усіх сферах медичної діяльності, використовуючи сучасні методи та методики, в тому числі моделювання клінічних ситуацій різних рівнів складностей, моделювання віртуальної реальності, “Стандартизований пацієнт”, систему психологічного консалтингу та менеджменту, а також гібридну симуляцію.

Мета медичної освіти - необхідність зменшення розриву між теорією і клінічною практикою. Місія симуляційних центрів полягає в навчанні, підтриманні, оновленні та оцінці технічної та теоретичної компетентності лікарів з використанням найсучасніших навчальних методів і технологій. Для перевірки компетентності та засвоєння виконання практичних навичок використовують брифінг, який полягає у презентації сценарію, та дебрифінг, під час якого студенти аналізують свої дії, оцінюють якість допомоги.

Центр координує свою роботу з провідними центрами симуляційних технологій світу і займається також перепідготовкою лікарів з інших регіонів 
України, які будуть готові працювати в умовах оновленої галузі. Стан медичної галузі підлягає реформуванню та потребує лікаря нової формації, який, крім теоретичних, має широкі практичні компетенції, що формуються за допомогою використання сучасних інноваційних технологій.

В сьогоденні в університеті розробляється методика та методичні підходи до впровадження в новому навчальному році комп’ютерної гри - симулятор “Віртуальний пацієнт”. Такий сучасний підхід до самостійної роботи студента навчить його правильно збирати анамнез, складати план ведення пацієнта, допоможе засвоїти протоколи обстеження та лікування пацієнтів, сформує клінічне мислення, навчить проводити диференційну діагностику, використовуючи сучасні дослідження. Цікавим є те, що студент матиме можливість простежити патологію пацієнта від біохімії і патофізіології до терапії або хірургії. В цій грі викладачі будуть відігравати роль пацієнта, а студенти - роль лікарів з оцінкою їх діяльності в балах. Бали мають враховуватися при визначенні рейтингу студентів та викладачів. Гра буде сприяти підвищенню компетентності випускаючих фахівців та підвищенню рівня професіоналізму викладачів.

Зразком сучасного підходу до створення належних умов для якісної освіти у вищих навчальних закладах медичного чи фармацевтичного профілів є університетські клініки та лікарні, приклад роботи яких у багатьох країнах світу надав поштовх для створення аналогічних установ в Україні.

Результати фундаментальних, прикладних та методичних досліджень, вітчизняний досвід, принципи доказової медицини широко впроваджуються співробітниками кафедр як в університетських клініках, так і на інших клінічних базах ОНМедУ, для чого використовуються відеосистеми та системи телекомунікаційних зв'язків. Налагоджено систему телемедичного консультування, яка на сьогодні охоплює 26 лікувально-профілактичних закладів області. Вченою радою університету прийнято рішення про надання цілодобової медичної допомоги населенню м. Одеси та області нашими клініками, багатопрофільним медичним центром та медичним офтальмологічним центром (пр. № 8, 25 травня 2015 р.).

Для підвищення якості соціально-педагогічного і психологічного супроводу навчально-виховного процесу, створення умов гармонічного розвитку і самореалізації інноваційного потенціалу осо- бистості студентів та викладачів цікаву форму суспільної діяльності широко використовують співробітники кафедр філософії і біоетики та соціальної допомоги, загальної і медичної психології, працюючи як практичні психологи. Їх діяльність включає консультативно-методичну допомогу, просвітницько-пропагандистську роботу та превентивне виховання.

Щорічно провідні науковці університету проводять тренінг-курси та майстер-класи з новітніх діагностичних та лікувальних технологій, а також самі відвідують міжнародні тренінг-центри, оволодіваючи новими методами профілактичної медицини та практичної охорони здоров’я.

У 2015 р. впроваджено 32 нових методи і модифікації методів діагностики, профілактики і лікування в практику 33 лікувально-профілактичних закладів.

Міжнародна робота ОНМедУ спрямована на підвищення якості навчання іноземних громадян та розвиток різнобічних зв'язків з міжнародними організаціями, одержання грантів, розробку спільних проектів, оптимізацію навчальної та наукової роботи з урахуванням сучасних тенденцій розвитку вищої школи та Європейської інтеграції.

У вересні 2015 р. ОНМедУ взяв участь у Першій Міжнародній професійній виставці з питань освіти 3НО-2016 (м. Київ), та отримав там нагороди - Гран-прі у номінаціях “Лідер інновації у діяльності навчального закладу “університет-новатор”, “Лідер інновації у розвитку міжнародної співпраці та презентації національної освіти у світовому та європейському освітньо-науковому просторі” та “Високий стиль сучасних програм, інноваційних підходів для підвищення якості освіти в контексті цивілізаційних змін”.

На міжнародній виставці “Інноватика в сучасній освіті” (Київ, 2015) за високі показники в роботі ОНМедУ отримав диплом за “Активне впровадження інноваційних технологій у процес навчання і виховання”, диплом лауреата конкурсу першого ступеня у номінації “Інновації у створенні системи внутрішнього забезпечення якості вищої освіти”.

Для активізації наукової діяльності та обміну досвідом навчальної роботи співробітники університету особливу увагу приділяють організації та участі в роботі міжнародних конференцій, конгресів, інших наукових форумів, виступаючи з доповідями з актуальних питань медичної та фармацевтичних галузей, зокрема питанням доказової медицини. В 
минулому навчальному році науково-педагогічним складом проведено на базі університету значну кількість наукових форумів різного рівня.

Висновок. На наш погляд, використання у навчальному процесі на базі симуляційного центру

\section{Список літератури}

1. Про вищу освіту : Закон України від 01.07.2014 р. № 1556-VII.

2. Запорожан В. М. Оптимізація освітньої діяльності університету відповідно до Закону України “Про вищу технології High Fidelity, створення умов для впровадження методики “Стандартизований пацієнт” та розробка гри симулятора "Віртуальний пацієнт” значно покращать якість освіти в університеті.

освіту” / В. М. Запорожан, В. Й. Кресюн, О. В. Чернецька // Медична освіта. - 2015. - № 2. - С. 53-55.

Отримано 01.04.16 